\title{
From Peshawar to Kabul: Preserving Afghanistan's Cultural Heritage during Wartime
}

This article profiles the Afghanistan Center at Kabul University (ACKU) as an example of an organization that has successfully engaged in preserving a nation's cultural heritage during a time of war. The ACKU has emerged from, and been engaged in, efforts to preserve Afghanistan's cultural heritage from the time of the Soviet occupation until today. Central to this story is the work of an American scholar, Nancy Hatch Dupree, who began to collect and preserve materials while she was in an Afghan refugee camp in Peshawar, Pakistan, in 1989. Those materials became the foundation for what is now the largest library and research center in Afghanistan. The story of the ACKU sheds light on how librarians, scholars, governments, and nongovernmental organizations can act in collaboration to preserve and protect cultural heritage in time of conflict.

\section{Historical Context}

The value of the historical and cultural archives in the Middle East and Near East regions cannot be overestimated. The Middle East and Near East regions are home to the oldest human civilizations, which spurred numerous advancements that have contributed in countless ways to modern society. One of mankind's earliest legal codes is the code of Hammurabi of Babylonia (r.1792-1750 BCE). ${ }^{1}$ The first agricultural irrigation system was used in the Nile Valley of Egypt more than 6,000 years ago, and the first known library was the Library of Alexandria, which was established in the third century BCE. ${ }^{2}$ The Middle East and Near East were home to the birth of three of the world's major religions: Judaism, Christianity, and Islam. Accordingly, many of the libraries and archives in Middle Eastern and Near Eastern countries have historical collections that date back to ancient times. For example, the archive of the Egyptian Museum has Egyptian manuscripts, some of which date back 4,000 years. ${ }^{3}$

\footnotetext{
1. “The World’s Oldest Writing." Archaeology 69, no. 3 (May 2016): 26-33.

2. Antonio Loprieno, Ancient Egyptian: A Linguistic Introduction (Cambridge University Press 1995), 12.

3. "4,000-Year-Old Ancient Egyptian Manuscript Measuring More Than $8 \mathrm{ft}$ Has Been Rediscovered in Cairo," Ancient Origins, September 14, 2015, available online at www.ancient-origins.net/news-history-archaeology / 4000-year-old-ancient-egyptian-manuscript-measuring-more-8ft-020526 [accessed 10 April 2016].

*C) 2016 by Laila Hussein Moustafa
} 
Afghanistan shares its border with Pakistan, Tajikistan, Iran, Turkmenistan, Uzbekistan, and China. According to archaeologist Louis Dupree, humans were living in Afghanistan at least 50,000 years ago, and they were the earliest humans to farm in their region. ${ }^{4}$ The country hosted many civilizations, including but not limited to Aryan Tribes in 20,000 BCE, the Achaemenid in 550 BC, and great waves of immigrants who moved from China to Afghanistan as a result of building the Great Wall in China. ${ }^{5}$ It has been a center for pilgrims, traders, nomads, and missionaries.

Afghanistan has a long history of war. Alexander the Great invaded the country in 326 BC, followed by conquest by the Greeks in 323 BCE. Many other civilizations came and sparred until the Muslim invasion in $642 \mathrm{CE}$. The Muslim invasion was followed by the Mongol invasion in 1219. In more recent history, the geostrategic location of Afghanistan attracted the attention of the Soviet Union and Great Britain. ${ }^{6}$ In the nineteenth and early twentieth centuries, Russia wanted to expand its power over Afghanistan and other countries in the region, such as British India. England, in return, supported the resistance against Russia. In 1879, the British divided Afghanistan by forcing the authorities to sign the Gandamak treaty that required Afghanistan to surrender several towns to British control. The British occupied Afghanistan from 1839 to $1921 .^{7}$ The British occupation was followed by the Russian occupation, which lasted from 1979 to 1989. Soon after the Russians left, the country entered the dark years of civil war from 1989 to 1996. As a result of civil war, the Taliban took control. The Americans then removed the Taliban regime in 2001 and Americans remain in Afghanistan today. As a result of the 2001 American invasion and internal conflict, the death toll of civilians from 2001 to 2016 is more than $26,000 .^{8}$ According to an Amnesty International report in 2016, Afghanistan has 1.2 million internally displaced people (IDPs) as a result of this conflict. ${ }^{9}$ Many of the IDPs are located in refugee shelters in cities like Heart, Kabul, and Mazar-e Sharif. IDPs face severe food and water shortages and lack healthcare and education. ${ }^{10}$

4. Louis Dupree, Afghanistan (Oxford: Oxford University Press, 1997), 3; Nancy Hatch Dupree, Panahae Tarikhee Afghanistan (Peshawar: Adarah kitabkhanah-i Sar Arik, 1998), 2.

5. Martin Ewans, Afghanistan: A Short History of its People and Politics (New York: Harper Perennial, 2002), 18 .

6. Louis Dupree, Afghanistan (Oxford: Oxford University Press, 1997), 421-22, 424, 443-44.

7. Paul Titus and Nina Swidler, "Knights, Not Pawns: Ethno-Nationalism and Regional Dynamics in Post-Colonial Baluchistan," International of Middle East Studies 32, no. 1 (2000): 47-69.

8. "Afghanistan Civilians," Costs of War, available online at http://watson.brown.edu/ costsofwar/ costs/ human/civilians/afghan [accessed 1 June 2016].

9. "Amnesty International Report," Amnesty International, available online at https:/ / www.amnesty.org/en/latest/news/2016/05/afghanistan-internally-displaced/ [accessed 2 May 2016].

10. Eugen Tomiuc, "Afghan IDP Problem Grows Despite Government Promises: Gandhara," Amnesty International, May 31, 2016, available online at http://gandhara.rferl.org/a/afghanistan-amnestyinternational/27768341.html [accessed 3 August 2016]. 
The long history of war in Afghanistan has devastated not just the people, but also the country's cultural heritage. According to the director of the National Library of Afghanistan (NLA), Mr. Fazlollah Qodsi, 80,000 books were lost during the civil war between 1989 and 2000; many were burned for heating or used to wrap food. During that time, 8 libraries out of 18 in Kabul were closed down, and some were converted into residential buildings. ${ }^{11}$ Recent wars have exacerbated the problem. For example, 90 percent of the country's archaeological sites have been looted, ${ }^{12}$ and 70 percent of the collection of the National Museum is missing. ${ }^{13}$ According to Carla Grissmann, an American artist and museum curator who played a role in the preservation of Afghanistan cultural and worked in Kabul Museum from 1980 to 1992 , the Kabul Museum was destroyed and looted in $1994 .{ }^{14}$ Along with the looting, the museum roof and top floor were destroyed. Fire destroyed the museum's official records and inventories, including the photographic room. In 1996, under the Taliban regime, 15 out of 18 libraries in Kabul were closed; in some cities, the library books were destroyed.

Unfortunately, research shows that most of the libraries and archives in this region are not prepared for any type of manmade or natural disasters. In a survey published in 2015, aimed at public and academic libraries and archives in Middle Eastern and Near Eastern countries including Afghanistan, I gathered information about the responding institutions and the emergency management plans that the institutions had in place for disasters and subsequent recovery. ${ }^{15}$ Eighty-six local public and academic managers, librarians, and archivists in nineteen countries responded to the survey. ${ }^{16}$ The vast majority of the institutions that responded, 84 percent, did not have a written disaster management plan. Only thirteen institutions responded affirmatively, and another five respondents answered that they were in the process of preparing plans. ${ }^{17}$ The results of this survey confirmed the lack of disaster management planning in the region's libraries and archives and revealed that, in times of conflict, most of those libraries and archives risk losing some or all of their collections.

11. "Reports from Afghanistan Reveal Kabul Libraries Devastated," American Libraries, February 2, 2002, available online at http:/ / americanlibrariesmagazine.org/ reports-from-afghanistan-reveal-kabullibraries-devastated/ [accessed 2 May 2016].

12. Brendan Cassar and Ana Rosa Rodriguez Garcia, "The Society for the Preservation of Afghanistan's Cultural Heritage: An Overview of Activities since 1994" in Art and Archaeology of Afghanistan: Its Fall and Survival, ed. Juliette van Kerieken-Pieters (Leiden: Brill, 2006), 15-38.

13. Nancy Hatch Dupree, "Museum under Siege," Archaeology Archive: A Publication of the Archaeological Institute of America, April 20, 1998, 22, available online at http: / /archive.archaeology.org/online / features/afghan/ [accessed 11 April 2016].

14. Carla Grissmann, "The Inventory of the Kabul Museum: Attempts at Restoring Order," Museum International, 55, no. $3 / 4$ (2003): 71-76.

15. Laila Hussein Moustafa, "Endangers Culture Heritage: A Survey of Disaster Management Planning in Middle East Libraries and Archives," Library Management 36, no. 6/7 (2015): 476-94, doi:10.1108/ LM-04-2015-0010.

16. Ibid., 483 .

17. Ibid., 483 . 
The loss of the collection of the National Library in Afghanistan during the civil war in 1989, and the destruction of many libraries in Iraq and Syria during the wars in the last ten years, demonstrate that libraries and archives in the Middle East are vulnerable to disaster, and irreplaceable collections are likely to be lost in time of war or conflict. Today, political and social turmoil in the region continues to threaten cultural heritage sites, including libraries and archives. In 2016, the region is facing numerous wars, including wars in Afghanistan, Iraq, Syria, Afghanistan, Libya, Yemen, and Sudan.

The question is: what can be done? History offers examples of how librarians and archivists have worked with other groups to save threatened collections. For example, archivists and librarians worked with the U.S. Army during World War II to create the Monuments, Fine Arts, and Archive program (MFAA). ${ }^{18}$ The creation of MFAA was the idea of a group of scholars from Harvard University who lobbied the American administration and encouraged the President of the United States to create a group of librarians, archivists, art historians, and other scholars to join the Army and work to save European cultural sites. ${ }^{19}$ The MFAA helped preserve European cultural heritage during the war and after. Similar work has also been carried out in the Middle East. For example, since 2014, a group of archeologists, scholars, and librarians from Syria and the United States have been working together to protect and save cultural sites and collections during the internal conflict. ${ }^{20}$

\section{Nancy Dupree and ACBAR}

In 1962, Nancy Hatch Dupree, a young American, went to Afghanistan and became interested in its history. She wrote several guidebooks about Afghanistan based on her travels inside the country, including a book titled History of Afghanistan. Later, when the Soviet Union invaded Afghanistan in 1979, Ms. Dupree had to leave the country. However, she did not go back to the United States; she went to live with Afghan refugees in Peshawar, Pakistan. Ms. Dupree's husband, Louis Dupree, was an archeologist who remained in Afghanistan until the Soviets arrested him because they accused him of working with the CIA as an agent. After he was expelled from Afghanistan, he joined his wife in Peshawar. ${ }^{21}$ There, both Ms. and Mr. Dupree established the Agency Coordinating Body for Afghan Relief (ACBAR) ${ }^{22}$

18. Robert M. Edsel and Bret Witter, Monuments Men: Allied Heroes, Nazi Thieves and the Greatest Treasure Hunt in History (London: Arrow Books, the Random House Group, 2010), 23.

19. Ibid., 23.

20. Salam al Quntar, Katharyn Hanson, Brian I. Daniels, and Corine Wegener, "Responding to a Cultural Heritage Crisis: The Example of the Safeguarding the Heritage of Syria and Iraq Project," Near Eastern Archeology 78, no. 3 (2015).

21. M. Jamil Hanifi, "Anthropology and the Representation of Recent Migrations from Afghanistan," Zero Anthropology, available online at https: / / zeroanthropology.net/all-posts/anthropology-and-therepresentation-of-migrations-from-afghanistan/ [accessed 17 August 2016].

22. A phone interview with the ACKU's manager, May 2016. 
The goal of establishing ACBAR was to collect published documents and books about Afghanistan as a way of preserving the country's heritage and helping Afghan refugees to learn and connect with their country and culture. Ms. Dupree collected and preserved important documents, flyers, and newspapers about the history of the country and the Soviet invasion, the Mujahedeen, and the Taliban. The agency focused on collecting government documents, materials from nongovernmental organizations such as the United Nations, and books from scholars around the world. According to The Economist's interview with Ms. Dupree, since 1978 many collections were lost as a result of the destruction of war or looting. She explained that those who sold the looted books did not even understand the value of the books; they sold them by the pound, and the pages of books were used to wrap food. ${ }^{23}$ Ms. Dupree was able to purchase a large number of rare books that were looted from Afghanistan and sold in Peshawar. By 1999, the collection contained a total of 7,739 titles, including 4,237 works in English, 2,387 in Dari, 905 in Pashto, and 210 in French, German, Norwegian, and Swedish. ${ }^{24}$

After the American and Coalition Forces invaded Afghanistan in 2001, Ms. Dupree did not immediately move back to Afghanistan because she was worried about the security of ACBAR's collection. However, in 2005, Ms. Dupree returned to Kabul and asked the Afghan government to provide her with a space to move the center's collection from Peshawar to Kabul. The government offered her shared space for the collection in Kabul University, but the collection of 36,000 documents, contained in 299 plastic fertilizer bags, needed a bigger space. Ms. Dupree petitioned the government for a new location for the ACBAR collection. American, Afghan, and Western European governments responded to her call and supported a new \$2 million building that housed the center under a new name: the Afghan Center at Kabul University (ACKU). The collection was moved to this new building in $2012 .{ }^{25}$

\section{The ACKU Today}

The ACKU is located in Kabul, Afghanistan, and is hosted by Kabul University. However, the university does not administer the center, and the center's budget is separate from the university's budget. ACKU is registered as a nongovernmental organization and receives support and funds from both private donors and governments ${ }^{26}$ who have supported the rebuilding of the national library and the establishment of the ACKU. The ACKU is collecting and preserving the intellectual heritage

23. “Preserving Afghanistan's Heritage: A Remarkable American Tries to Salvage Written Records of a Ravaged Time, The Economist, December 8, 2012, available online at www.economist.com/news/ asia / 21568001-remarkable-american-tries-salvage-written-records-ravaged-time-paper-work [accessed 21 May 2015].

24. Afghanistan Centre at Kabul University (ACKU), available online at www.dupreefoundation.org/ acku.htm [accessed 2 April 2016].

25. A phone interview with the ACKU's manager, May 2016.

26. Ibid. 
of the people of Afghanistan and has the largest collection in Afghanistan, collected since the Soviet Union's war against Afghanistan in 1989. The center works with local and international institutes and organizations to collect the hidden and dispersed archives of Afghan books and other materials; it continues to look for looted or privately owned materials to be preserved.

The center is the repository of the materials about Afghanistan that were collected by Prof. Louis Dupree and Nancy Dupree in Peshawar during the Soviet invasion of Afghanistan, including the UN report related to the refugee humanitarian operations and remnants of the original library collection from the refugee camps, which included publications in both Dari and Pashto, the main two languages of Afghan people. The center continues to collect displaced materials that are still missing or held privately, ${ }^{27}$ organizes cultural events, and hosts seminars, workshops, conferences, exhibitions, and musical and film events.

Today the library has 96,629 titles, including 4,700 books in the reference section, 30,000 books in the reading hall, 2,500 novels and history books, 5,530 poetry books, 50,000 rare books, 1,000 maps, 100 manuscripts, and some children's books. ${ }^{28}$ The collection includes media materials related to the Mujahedeen period, CDs and DVDs, audio and videocassettes, and 100,000 items of Afghan newspapers and foreign newspapers covering issues like Afghan government, the political history of the Soviet occupation (1979-1989), the civil war of the early 1990s, and the Taliban era (1996-2001). Some titles do not exist in other places because not many books or journals survived the wars.

The new ACKU building occupies 5,700 square meters and two floors. The first floor houses a conference room, librarians' offices, catalogers, acquisition specialists and those who work on digitization, administrators, and a reading room with many computers and Internet connections. Part of the computer room is for users of audiovisual material, and there are private reading rooms for long-term researchers.

From March to May 2016, I interviewed a manager of the ACKU to learn more about the history of the collection, the establishment of the center, the challenges the center faces, and its future plans to preserve its collection. To protect the manager's confidentiality, I refer to him as "Raji Sharif." I conducted seven interviews with Mr. Sharif during a two-month period, including three online phone interviews and four interviews by e-mail, using forty-five questions that served as the

27. Ibid.

28. Qayoom Suroush, "Reading in Kabul: The State of Afghan Libraries," Afghanistan Analysts Network, April 9, 2015, available online at https: / / www.afghanistan-analysts.org/reading-in-kabul-the-stateof-afghan-libraries/ [accessed 12 April 2016]. 
basis for our semistructured interviews (see appendix A), and I shared the questions with Mr. Sharif before our first phone call.

The center's materials often require special handling, and in 2007 they started to digitize some of its rare collections. They have now digitized around 1,478,506 pages and more than 41,539 PDFs of books, serials, and newspapers, along with 10,000 photographs from Professor Louis Dupree. The ACKU collaborated with the University of Arizona to digitize 15,000 rare books and newspapers, and all the digitized materials are available at ACKU's website. In 2007 the ACKU also received a grant of $\$ 300,000$ from the National Endowment for the Humanities to purchase equipment, pay salaries, and use for other expenses. The grant helped provide access to previously hidden materials in the most extensive collection in the region covering different wars and social unrest in the country. ${ }^{29}$

Mr. Sharif reported that the center provides services like any research center. It is open to students and other scholars from within the country and around the world. The center hosts 500 visitors a year, including 5-8 foreign researchers. The ACKU serves the University of Kabul's students, which is important because the university library was looted in 2001 and the library is still rebuilding its collection. Users are allowed to photocopy the materials they need. However, books may not be checked out, in an effort to protect the collection. ${ }^{30}$

\section{Partnerships and Support}

According to Mr. Sharif, the center receives funds from two major donors: the Royal Norwegian Embassies and USAID. It also receives funds from other governments. For instance, the Estonian government helped fund the installation of the center's computer system and supplied new scanners. The government of Switzerland, the Open Society organization, and USAID supported the establishment of the center, and they support Ms. Dupree's mobile library project.

The mobile library project began in 1996 as the ARIC Box Library Extension Project (ABLE), in cooperation with the United Nations, the Red Crescent Society, and the Ministry of Information and Culture. By 1999, the project had 30 mobile libraries operating in 22 provinces and a total of 9,236 books and magazines. ${ }^{31}$ Today, the mobile library program has two goals: to open small libraries to lend books to people in high school and in communities across the country, and to publish books.

\footnotetext{
29. Afghanistan Digital Collections, The University of Arizona-University Libraries-Afghanistan Center at Kabul University, available online at www.afghandata.org/ [accessed 5 May 2016].

30. A phone interview with the ACKU's manager, May 2016.

31. Nancy Hatch Dupree, "Library in Afghanistan," Intentional Preservation News - International Federation of library Associations and Institutions (IFLA), 19, no. 3 (July 1999): 21-27, available online at www.ifla. org/publications/international-preservation-news [accessed 14 May 2016].
} 
The project aims to establish a small library in different communities and in every province for high school students in Afghanistan.

ABLE has shown a high commitment to expanding its libraries each year, and new locations are opening across the country. The project now has a close cooperation with the Ministry of Education to expand and update its school libraries. ABLE has succeeded in establishing 193 ABLE libraries within high schools across the country, and the program provides materials that cover general subjects. The project opens libraries in mosques, clinics, and social institutions, providing materials that target children, farmers, housewives, and other ordinary people. The goal is to spread the idea of reading. Each "box library" has two shelves and carries 200 Dari and Pashto books, magazines, pamphlets, and posters on different subjects, such as agriculture, family, Islam, literature, and children's books. The second part of ABLE is the publications. ABLE publishes new literature in the Dari and Pashto languages. The publications cover topics like health, agriculture, history, and home management. As of 2016, the total production of the project is 324 titles in Dari and Pashto languages. ${ }^{32}$

\section{ACKU's Future Plans}

ACKU plans to translate many items in its collections from Dari/Pashto to English. It plans to digitize all of the Afghani legislative documents and more than 150,000 historical photos, some of which are a hundred years old. Another important project is digitizing all of the Afghanistan Official Gazette. This project is funded by USAID, with the goal of helping to develop the justice sector and give access to published law. In addition, one of the latest projects that the ACKU is leading is the establishment of a library association in Afghanistan that will bring all libraries in the country under one umbrella so they can work together and exchange information and experience. ${ }^{33}$ The center would like to have the support of the international community to promote libraries in Afghanistan and offer training to those who work in libraries in the country. The ACKU wants international organizations, such as UNESCO, to help recover looted books that moved outside the country during the last decades of wars.

\section{Challenges}

The ACKU faces many challenges as it continues its efforts to preserve Afghanistan's cultural heritage, including lack of skills and funds. Mr. Sharif addressed one of the challenges that the library faces, which is that staff lack significant levels of professional training, particularly related to cataloging, digital preservation, and archiving. In short, they are lacking the skills of professional librarians. This

32. A phone interview with the ACKU's manager, May 2016.

33. Ibid. 
challenge is not surprising, given the fact that Afghanistan has never had a library school and there are limited opportunities for professional development. The issue of training is not new in the field of librarianship in Afghanistan. UNESCO made a recommendation in its 1977 report that the librarians in Afghanistan should be sent outside the country for training in descriptive bibliography and archives. ${ }^{34}$

The center does not have an archives or preservation unit, and it does not have professional conservation staff who can help prepare items before they are digitized. The limitations of funding and the lack of skilled people challenge the center's progress in preserving its materials. According to Mr. Sharif, "Having all the collection in one location in unstable countries without being digitized is worrying everyone in the center." A lack of funds prevents the center from digitizing its materials, and the ACKU does not have a disaster plan. The center does not have a ventilation system, either; what they have are exhaust fans to regulate temperature in the library stacks. Mr. Sharif is also concerned about the center's security; however, it is not the first priority because of the shortage of funds.

\section{Conclusion}

The story of the ACKU, and the initial efforts of Nancy Dupree to save and protect the heritage of Afghanistan in time of war, shows the importance of commitment and collaboration among librarians, scholars, educational institutions such as the University of Arizona, and local, national, and international governments, organizations, and donors. While local efforts by citizens are largely responsible for the hiding and storage of materials, evacuating archives to more secure locations required advanced planning and dedicated, large-scale collaborations among cultural heritage institutions and governments.

Unfortunately, the story of how the collection was assembled and preserved is incomplete. In the last ten years, many universities and cultural heritage institutions in Europe and the United States have started to preserve and digitize some of the surviving Afghani materials, ${ }^{35}$ but how materials were gathered and archived in the refugee camp is unknown. The journey of the surviving items and the professional interactions with the items are important, because they are instructive for those who wish to protect their own cultural heritage during times of conflict or war.

34. John J. Eyre, "Republic of Afghanistan: Assistance to Member States for the Development of National Documentation, Library and Archives Infrastructures," report prepared for the Government of the Republic of Afghanistan by the United Nations Educational, Scientific and Cultural Organization (UNESCO), (UNESCO, 1977) Serial No. FMR/CC/DBA/77/115, available online at http://unesdoc. unesco.org/images/ 0002/000243/024341eo.pdf [accessed 2 April 2016].

35. Afghanistan Digital Library at New York University in New York, a project that aims to retrieve and restore some of Afghanistan's published cultural heritage. The project is collecting, cataloging, and digitizing many publications from the period 1871-1930, and it is available online at http://afghanistandl.nyu.edu/ [accessed 10 May 2016]. 
Cultural heritage professionals need to document these stories when they preserve and catalogue a surviving cultural heritage item so that the journey of an item can remain part of the material's history.

Wars destroy human lives and people's cultural heritage. Rebuilding what was destroyed and looted during conflict or war can take years of work and millions of dollars. The project of the ACKU, which Nancy Dupree sponsored for more than thirty-five years, demonstrates how local people, librarians, scholars, governments, and nongovernmental organizations can act in collaboration to preserve and protect cultural heritage in a time of war. There is more to be learned in this area, though, and future studies could continue to shed light on how to preserve cultural heritage collections in libraries and archives in times of conflict.

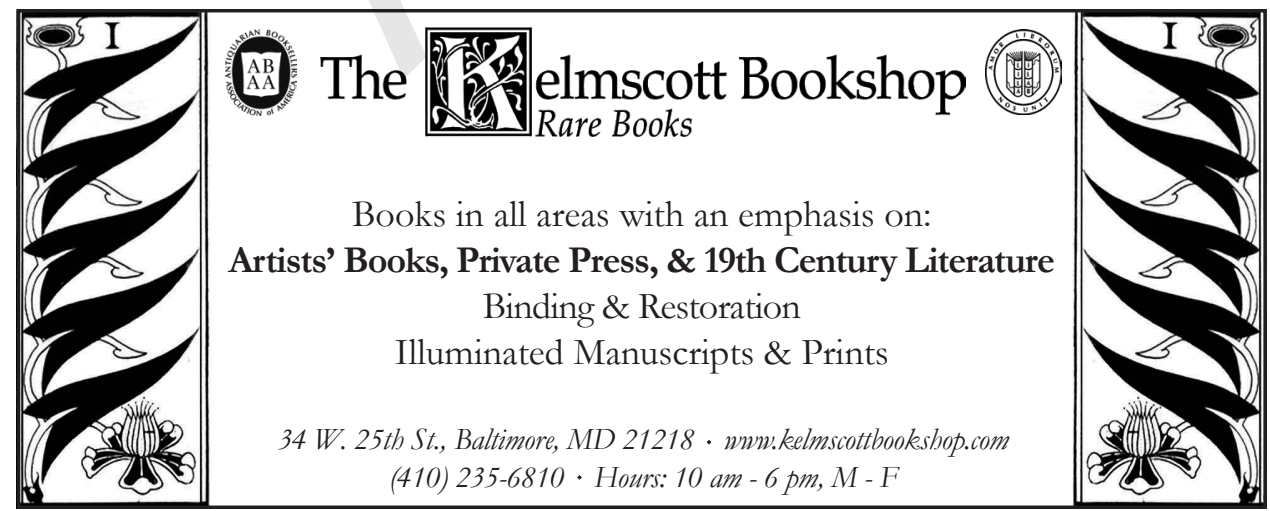




\section{APPENDIX A. Interview Questions}

\section{Background Information}

1. Is your library:
a. National
b. Public
c. Associated with a higher education institute such as a College
d. Other

\section{Collection Type}

2. What type of collection does your library house?
a. Books
b. Newspapers
c. Manuscripts
d. Oral History Documents
e. Maps
f. Journals/Magazines
g. Cassettes
h. DVDs

\section{Preservation Plan}

3. Does your library have a staff member or more whose job is to lead the preservation activity?

- Yes

No

4. How many people work in the preservation unit?
a. professional staff
b. support staff
c. part-time staff

5. How many full-time staff work in the following:
a. digital curation digital preservation
b. audio/video preservation
c. microfilming
d. other

\section{Preservation Activities}

6. Does your library undertake binding of books or other materials?
a. Can you give me your best guess of how many monographs you are bind- ing annually?
b. How many serials are you binding annually?

7. Please let me know if you have had an accident; for example, with water, mold, insects, fire and other.

8. Has your library had any situations where water or mold affected the books?
a. How about insects?
b. What about fire?
c. Or anything else 
9. Were you able to take steps to do anything to control the situation and preserve the books or other materials?

10. How many times did you face such a situation in the last 10 years?

11. Does your library use any devices to monitor the environment?

a. HVAC system records temperature

b. We do not monitor the environment

12. Do you have any way to control the temperature inside the library?
a. Light inside the library
b. Air quality inside the library
c. Humidity inside the library

\section{Conservation}

13. Do you have a staff member in the library who works in conservation treatment?

14. Does your institute outsource conservation treatment?

15. What percentage of the items receives conservation treatment for:
a. Books and bound volumes
b. Photo collection
c. Others

16. Do you reformat newspapers and images to the digitized format?
a. To create access copy
b. Replace damaged items
c. Cost effect
d. Help to have extra funds

17. Do you participate in digitization of the collection with:
a. Google BOOK
b. HathiTrust
c. Internet Archive
d. Lockss
e. Other

18. What percentage of the following were digitized:
a. Books
b. Newspaper
c. Photo
d. Sound record
e. Moving image

19. Which of the following digitization activities does your library perform for its collection?
a. Record preservation metadata
b. Maintain multiple copies on redundant storage media
c. Migrate content to new file formats
d. Disaster planning and recovery
e. Other 
20. For each item that you digitize, how many copies do you have?

21. Which repository platform does your library use:
a. Dspace
b. Exlbiris
c. Fedora
d. Digital commons
e. Other
f. No repository

\section{Emergency Plan}

22. Who is responsible for the Emergency Management Plan in your institute?

23. Does your library/archive have an emergency management plan written? Yes No

24. Who wrote the plan?
a. A staff member
b. External consultant officer
c. Do not know
d. Other

25. When was the last time your library updated the emergency plan?
a. In the last 12 months
b. In the last 2-3 years
c. Other

\section{Training}

26. Who receives the training to use the emergency management plan?
a. You
b. Your staff

27. Who is responsible for taking care of checking for safety in the library?

28. Who is responsible for planned building maintenance?

29. Who is responsible for checking the security of the collections?

30. Do you have fire equipment and who is checking it?

31. Do you have installation of automatic fire suppression? Who did the installation?

32. Does your staff have appropriate knowledge of what to do in case of an emergency? Such as where to go? Who to contact?

33. What prevents you from having emergency planning?
a. We do not have funds devoted to it
b. We do not have a trainer 
34. Do you think it is important to have a DMP in your library because of:
a. Security
b. Condition of the building
c. Vandalism

\section{International Support}

35. Do you have any support from individuals, international organization such as UNESCO, Blue Shield, or others who are not from this country?

36. What support do you have to train your staff to:
a. Catalogue
b. Digitize
c. Archive
d. Preservation
e. Buying equipment

37. In the last three years, how many trainings have the international groups or individuals offered you?
a. Your staff
b. Your archivist
c. Your digital person
d. Your catalogers
e. Others

38. Where was it held?

39. How many people from your library attended the training?

40. What was the topic of the training?

41. How was it decided who should get the training?

42. How long did the training last?

43. Was there any follow-up from the training provider?

44. What is other training that your staff needs?

45. What other assistance would you like from the international groups who work with libraries or work in your country? 